\title{
Antiproliferative Effects of Cannabinoid Agonists on Deep Infiltrating Endometriosis
}

\author{
Mahaut Leconte, ${ }^{* \dagger}$ Carole Nicco, ${ }^{*}$ Charlotte Ngô, ${ }^{* \neq}$ \\ Sylviane Arkwright, ${ }^{\S}$ Christiane Chéreau, ${ }^{*}$ \\ Jean Guibourdenche, "iा Bernard Weill, ${ }^{*}$ \\ Charles Chapron, ${ }^{\ddagger}$ Bertrand Dousset, ${ }^{\dagger}$ \\ and Frédéric Batteux*

\begin{abstract}
From the Laboratoire d'Immunologie," Universite Paris Descartes, Paris; the Department of Digestive and Endocrine Surgery, ${ }^{\dagger}$ the Department of Obstetrics and Gynecology II and Reproductive Medicine, ${ }^{\ddagger}$ the Department of Pathology, ${ }^{\S}$ and the Department of Hormonology, "Tôpital Cochin, Assistance Publique, Hôpitaux de Paris, Paris, France
\end{abstract}

Deep infiltrating endometriosis (DIE) is characterized by chronic pain, hyperproliferation of endometriotic cells and fibrosis. Since cannabinoids are endowed with antiproliferative and antifibrotic properties, in addition to their psychogenic and analgesic effects, cannabinoid agonists have been evaluated in DIE both in vitro and in vivo. The in vitro effects of the cannabinoid agonist WIN 55212-2 were evaluated on primary endometriotic and endometrial stromal and epithelial cell lines extracted from patients with or without DIE. Cell proliferation was determined by thymidine incorporation and production of reactive oxygen species by spectrofluorometry. ERK and Akt pathways were studied by immunoblotting. Immunoblotting of $\alpha$-smooth muscle actin was studied as evidence of myofibroblastic transformation. The in vivo effects of WIN 55212-2 were evaluated on Nude mice implanted with human deep infiltrating endometriotic nodules. The in vitro treatment of stromal endometriotic cells by WIN 55212-2 decreased cell proliferation, reactive oxygen species production, and $\alpha$-smooth muscle actin expression. The decrease in cell proliferation induced by WIN 55212-2 was not associated with a decrease in ERK activation, but was associated with the inhibition of Akt activation. WIN 55212-2 abrogated the growth of endometriotic tissue implanted in Nude mice. Cannabinoid agonists exert anti-proliferative effects on stromal endometriotic cells linked to the inhibition of the Akt pathway. These beneficial effects of cannabinoid agonists on
DIE have been confirmed in vivo. (Am J Pathol 2010, 177:2963-2970; DOI: 10.2353/ajpath.2010.100375)

Endometriosis, a common disease that affects about 6 to $10 \%$ of women of childbearing age, ${ }^{1}$ is characterized by the presence of endometrial tissue outside of the uterine cavity. ${ }^{1,2}$ Deep infiltrating endometriosis (DIE) is an aggressive form of the disease that involves muscularis regardless of location (bladder, intestine, ureter, etc.). ${ }^{3}$ DIE is responsible for chronic pelvic pain whose intensity is correlated with the depth of lesions, ${ }^{4,5}$ and induces disability $^{6}$ and infertility. ${ }^{7}$ In DIE, the tissular lesion includes fibrosis in addition to the endometrial tissue (endometriotic gland, simple endometrial epithelium with stroma). The presence of fibrosis in DIE explains the low hormonal dependence of lesions and the difficulties in surgical resection. ${ }^{8}$ The medical treatments currently used are based on hormonal therapy that blocks ovarian function, but whose effects are transient. Therefore, surgical resection of the lesions is the only curative treatment. Surgery is often necessarily extensive and is associated with significant morbidity. ${ }^{9}$ It would be interesting to find an alternative medical treatment that targets the hyperproliferative phenotype of endometriotic cells which is associated with increased endogenous oxidative stress and activation of the ERK pathway. ${ }^{10}$

The cannabinoids are well known for their psychogenic effects and their role in inflammation and immunity. ${ }^{11}$ They are also endowed with properties that can be used in the control of three major aspects of DIE: hyperproliferation, fibrosis, and chronic pain. Because of their implication in proliferation, apoptosis, and angiogenesis, the cannabinoids control cell growth. ${ }^{12-14}$ Their antiproliferative effects result from the inhibition of growth factors $^{15,16}$ and the deregulation of such signaling pathways as Ras-Raf-MKKK1-ERK1/2, ${ }^{17}$ PI3K-Akt/PKB-mTOR ${ }^{18}$ and C-Jun N-terminal kinase-MAPK. ${ }^{19}$ These mechanisms

\footnotetext{
Supported in part by funds from Paris Decartes University. B.D. and F.B. contributed equally to the direction of this work. Accepted for publication August 19, 2010.

Address reprint requests to Frédéric Batteux, M.D., Ph.D., Laboratoire d'immunologie, Hôpital Cochin, 75679 Paris cedex 14. E-mail: frederic. batteux@cch.aphp.fr.
} 
have suggested new targets in cancer treatment ${ }^{20}$ and also in endometriosis, since endometriotic cells have a hyperproliferative phenotype and pro-angiogenic properties. ${ }^{21}$ In addition, several experimental studies have reported an antifibrotic role of cannabinoid agonists. ${ }^{22-28}$ If such antifibrotic effect of cannabinoid agonists could be demonstrated in DIE it would allow a less extensive surgery. Finally, cannabinoids have analgesic properties and have been used for a long time in treating chronic pain. ${ }^{29-31}$

Therefore, we have evaluated the effects of cannabinoid agonists in vitro on cells extracted from biopsies of deep infiltrating endometriosis and in vivo on a mouse model of endometriosis. We conclude from our data that cannabinoid agonists represent a promising approach in the treatment of DIE.

\section{Materials and Methods}

\section{Sample Collection}

Biopsies of eutopic endometrium and deep infiltrating endometriotic nodules were obtained from 14 patients undergoing surgical treatment for DIE with rectal involvement. Low rectal endometriosis was defined preoperatively, based on the following clinical and endoscopic ultrasonographic criteria: a) rectal invasion of the infraperitoneal rectum located within $8 \mathrm{~cm}$ of the dentate line, reachable on rectal examination; and b) full-thickness invasion of the muscular layer greater than $15 \mathrm{~mm}$ on rectal endoscopic ultrasonography. ${ }^{9}$

DIE was confirmed in all cases by a pathologist experienced in endometriosis pathology (S.A.). All of the patients had been treated by luteinizing hormone releasing hormone agonists before surgery since for at least one month. Control endometrial specimens were obtained from 12 patients without macroscopic endometriosis undergoing laparoscopy for other reasons (tubal infertility, nonendometriotic ovarian cyst, myoma). Ethics approval for this study has been obtained from the ethics committee at Cochin Hospital (n05-2006 "génomique et protéomique de l'endométriose"). Written informed consent was obtained from each patient and control. Specimens were collected under sterile conditions and immediately transported to our laboratory in Dulbecco's modified Eagle's medium (Gibco Invitrogen, Cergy Pontoise, France) with $10 \%$ fetal calf serum. No steroid hormones were added in cell culture. Estrogen $\left(\mathrm{e}_{2}\right)$ and progesterone $\left(\mathrm{p}_{4}\right)$ were undetectable in cell culture supernatants as determined by an immunodiagnostic system (Advia CentaurXP, Siemens, Health Care Diagnostics, France, SaintDenis). The absence of steroid hormones in culture supernatants reproduces clinical conditions in patients submitted to a treatment by luteinizing hormone releasing hormone agonists. The period of time elapsed between the biopsy and the procedure of cell isolation never exceeded 1 hour. The same culture medium was used throughout the study.

\section{Cell Isolation and Culture}

Primary endometrial and deep endometriotic cell cultures were prepared from biopsies as described. ${ }^{32}$ Biopsy specimens were rinsed and minced into small pieces then digested with $5 \%$ dispase and collagenase $(2 \mathrm{mg} /$ $\mathrm{ml}$, Gibco Invitrogen, Cergy Pontoise, France) for 1 hour at $37^{\circ} \mathrm{C}$ and separated using serial filtration. Red blood cells were removed by hypotonic lysis $\left(0.15 \mathrm{~mol} / \mathrm{L} \mathrm{NH}_{4} \mathrm{Cl}\right.$, $1 \mathrm{mmol} / \mathrm{L} \mathrm{KHCO}_{3}, 0.1 \mathrm{mmol} / \mathrm{L} \mathrm{Na} \mathrm{NDTT}_{2}$. Debris was removed using 100- $\mu \mathrm{m}$ aperture sieves. Epithelial cells were retained on $40-\mu \mathrm{m}$ aperture sieves while stromal cells remained in the filtrate. Both cells were plated onto Primaria flasks (Becton Dickinson Labware, Le Pont de Claix, France) and cultured in Dulbecco's modified Eagle's medium (Gibco Invitrogen, Cergy Pontoise, France) with $10 \%$ fetal calf serum. For each patient with DIE, four cell populations were obtained: eutopic endometrial stromal cells (Es), eutopic endometrial epithelial cells (Ee), deep infiltrating endometriotic stromal cells (Ds), and deep infiltrating endometriotic epithelial cells (De). For each control, we used two cell populations: control endometrial stromal cells (Cs) and control endometrial epithelial cells $(\mathrm{Ce})$.

The purity of stromal and epithelial cell suspension was assessed by staining with 1:100 fluorescein isothiocyanate-labeled anti-cytokeratin and 1:100 Cy3-labeled antivimentin antibodies (Sigma Aldrich, St. Louis, MO). Fluorescence was analyzed using an Olympus fluorescent microscope (Hambourg, Germany) and images were captured using the Cell Imaging station (Olympus). Both populations were negative for CD3 ( $T$ cells), CD45 (leukocytes), and CD11b (monocytes and granulocytes) staining. All of the experiments were performed on primary cultures of each cell population and the various tests were performed in triplicates.

\section{Cell Proliferation and Viability Assays}

The cells that had reached confluence were harvested following trypsin treatment. Cells $\left(10^{4}\right.$ per well) were seeded in 96-well plates (Nunc, Roskilde, Denmark) and incubated for 48 hours in Dulbecco's modified Eagle's medium with $10 \%$ fetal calf serum at $37^{\circ} \mathrm{C}$ under $5 \% \mathrm{CO}_{2}$ alone or with various concentrations of WIN 55212-2 (from $0.3 \mu \mathrm{mol} / \mathrm{L}$ to $40 \mu \mathrm{mol} / \mathrm{L}$ as described in figure legends). Cell proliferation was determined by pulsing the cells with $\left[{ }^{3} \mathrm{H}\right]$-thymidine $(1 \mu \mathrm{Ci}$ per well, Amersham, GE Health care) during the last 18 hours of culture ${ }^{33}$ and measuring the radioactivity incorporated by liquid scintillation counting. Results are expressed as counts per minutes (cpm).

Cell viability was analyzed by Hoechst 33342 staining (Molecular Probes). Cells were incubated in $100 \mu \mathrm{l}$ PBS with $1 \mu \mathrm{g} / \mathrm{ml}$ Hoechst 33342 for 30 minutes. Fluorescence intensity was recorded at the end of the incubation with a fluorescence excitation/emission maxima of $350 / 461 \mathrm{~nm}$. 


\section{Cellular Production of Reactive Oxygen Species}

Cells ( $10^{4}$ per well) were seeded in 96-well plates (Nunc, Roskilde, Denmark) and incubated for 18 hours alone or with various concentrations of WIN 55212-2 (from 0.3 $\mu \mathrm{mol} / \mathrm{L}$ to $40 \mu \mathrm{mol} / \mathrm{L}$ as described in figure legends). Cellular levels of $\mathrm{O}_{2}^{--}, \mathrm{H}_{2} \mathrm{O}_{2}$ and nitric oxide (NO) were assessed by spectrofluorometry using the oxidation of $125 \mu \mathrm{mol} / \mathrm{L}$ dihydroethidium (DHE) (Interchim, Montluçon, France), $100 \mu \mathrm{mol} / \mathrm{L}$ 2',7'-dichlorohydrofluorescein diacetate (H2DCFDA) (Molecular Probes, Eugene, OR) and 4',5'-diaminofluorescein diacetate (DAF2DA) (Sigma Aldrich, Saint Quentin-Fallavier, France) respectively, during 5 hours. The levels of $\mathrm{O}_{2}^{--}, \mathrm{H}_{2} \mathrm{O}_{2}$, and $\mathrm{NO}$ were calculated in each sample as follows: reactive oxygen species rate (arbitrary units $/ \mathrm{min} / 10^{4} \mathrm{cells}$ ) $=$ (fluorescence intensity [arbitrary unit] at T 300 minutes - fluorescence intensity [arbitrary unit] at T 0/300 minutes/number of cells. ${ }^{33}$

\section{Immunoblotting of Cell Lysates}

Untreated cells or cells treated by $20 \mu \mathrm{mol} / \mathrm{L}$ of WIN 55212-2 were lysed in ice-cold radioimmunoprecipitation assay buffer $(10 \mathrm{mmol} / \mathrm{L}$ TrisHCl, $\mathrm{pH} 7.5,5 \mathrm{~mol} / \mathrm{L} \mathrm{NaCl}$, $1 \%$ Triton X-100, $0.1 \%$ SDS) supplemented with 25 $\mathrm{mmol} / \mathrm{L}$ sodium fluoride, $0.5 \mathrm{mmol} / \mathrm{L}$ sodium orthovanadate, and 1\% anti-protease. Equal amounts of proteins (30 $\mu \mathrm{g}$ ) were loaded and separated by 10\% SDS-polyacrylamide gel electrophoresis. Transfer and blocking experiments were performed. For CB1 and CB2 staining, polyvinylidene difluoride membrane was saturated with $5 \%$ skim milk for 1 hour, then incubated with rabbit antihuman CB1 lgG antibodies or with rabbit anti-human CB2 IgG antibodies (Interchim, Montluçon, France) overnight at $4^{\circ} \mathrm{C}$. For ERK and pERK staining, polyvinylidene difluoride membrane was saturated with $5 \%$ skim milk 1 hour then incubated with rabbit anti-human ERK IgG antibodies and rabbit anti-human pERK IgG antibodies (Santa Cruz Biotechnology, Santa Cruz, California) overnight at $4^{\circ} \mathrm{C}$. For $\alpha$-smooth muscle actin (SMA) staining, polyvinylidene difluoride membrane was saturated with $5 \%$ skim milk 1 hour, and then incubated with mouse antihuman $\alpha$-SMA IgG antibodies (Sigma Aldrich, St. Louis, $\mathrm{MO})$ overnight at $4^{\circ} \mathrm{C}$.

The binding of specific antibodies was revealed using horseradish peroxidase-conjugated goat anti-rabbit IgG antibodies for CB1, CB2, ERK, or pERK, or horseradish peroxidase-conjugated goat anti-mouse IgG antibodies for $\alpha$-SMA, then visualized by an Enhanced ChemoLuminescence system (Pierce Perbio Sciences, Brebières, France). ${ }^{34}$

\section{Mouse Model}

Fourteen Nude mice were grafted with two fragments of a nodule from one patient with DIE. Female nude mice between 6 and 8 weeks of age weighing 20 to $22 \mathrm{~g}$ were used in this study. Animals received humane care in compliance with institutional guidelines. Mice were anesthetized with intraperitoneal injections of Avertine. An incision was made on the ventral midline and two fragments of human endometriotic nodules were sutured to the parietal peritoneum with $7 / 0$ prolene. Each fragment was measured using a rule caliper. An additional fragment was fixed with $10 \%$ formol and set in paraffin for initial histological analysis. The abdominal wall was sutured with a 6/0 nylon thread. ${ }^{35}$ A subcutaneous injection of $0.5 \mu \mathrm{g} \beta$-estradiol was performed on day 1 and day 2 to facilitate the implantation of endometriotic nodules. ${ }^{36}$

On day 7 after implantation, mice were operated to confirm the viability of the implant. Treatment started on day 7: the treated group received intraperitoneal injections of WIN 55212-2 (3 mg/kg in $100 \mu$ l of PBS, 5 days a week for 2 weeks) and the control group received intraperitoneal injections of $100 \mu \mathrm{l}$ PBS under the same conditions. After 2 weeks of treatment, animals were sacrificed by cervical dislocation. Implants were extracted, measured. The volumes of the implant were calculated as follows: TV $\left(\mathrm{mm}^{3}\right)=\left(\mathrm{L} \times \mathrm{W}^{2}\right) / 2$, where $\mathrm{L}$ is the longest and $W$ the shortest radius of the tumor in millimeters. Results were expressed as means of tumor volumes $\pm \mathrm{SE}$.

\section{Statistical Analysis}

All of the results are the means of independent triplicate experiments for each cellular population from each patient. Means were compared by the Student's test. A level of $P<0.05$ was accepted as significant.

\section{Results}

\section{Biopsies}

Fourteen patients were included in the study. Twelve biopsies of eutopic endometrium and 14 biopsies of deep endometriotic nodules were obtained from those patients. Twelve Ee cell lines and 12 Es cell lines were extracted from 12 samples of eutopic endometrium and 14 De cell lines and 14 Ds cell lines were extracted from 14 samples of deep infiltrating endometriotic nodules. Four cell lines were eliminated for failure of culture $(n=3)$ or bacterial contamination $(n=1)$. Finally, 10 Ee cell lines, 11 Es cell lines, 13 De cell lines, and 14 Ds cell lines could be studied.

Twelve control women were included in the study. Twelve biopsies of healthy endometrium were obtained. The 12 samples of endometrium provided 12 epithelial and stromal control endometrial cell lines. Three cell lines were eliminated for failure of culture. Finally, $11 \mathrm{Ce}$ cell lines and $10 \mathrm{Cs}$ cell lines have been used in this study.

\section{Expression of Cannabinoid Receptors CB1 and CB2 by Endometriotic Cells}

The CB1 and CB2 receptors were equally present in the epithelial and stromal cell lines derived from eutopic endometrium (Ee, Es) and deep infiltrating endometriotic nodules (De, Ds) (Figure 1). 


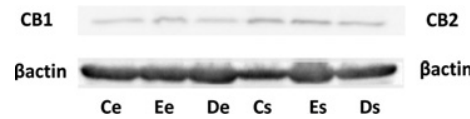

Ce Ee De Cs Es Ds

Ce Ee De Cs Es Ds

Figure 1. Expression of $\mathrm{CB} 1$ and $\mathrm{CB} 2$ on endometriotic cells. Expression of cannabinoid receptors $\mathrm{CB} 1$ and $\mathrm{CB} 2$ was determined by western blots on each cell line lysate: 10 eutopic endometrial epithelial cell lines (Ee), 11 eutopic endometrial stromal cell lines (Es), 13 deep infiltrating endometriotic epithelial cell lines (De) and 14 deep infiltrating endometriotic stromal cell lines (Ds), 11 control endometrial epithelial cell lines (Ce), and 10 control endometrial stromal cell lines (Cs). The figure represents one representative Western blot obtained with all of the cell lines extracted from one patient and from one control. CB1 and CB2 are equally present in Ce, Ee, De, Cs, Es, and Ds cells.

\section{Effect of WIN 55212-2 on the Proliferation of Endometriotic Stromal Cells}

The Es, Ds, and Cs cells were treated with increasing concentrations of WIN 55212-2 (0.3 $\mu \mathrm{mol} / \mathrm{L}$ to $40 \mu \mathrm{mol} / \mathrm{L})$. At the highest concentration $(40 \mu \mathrm{mol} / \mathrm{L})$, the proliferative rate of Es, Ds, and Cs cells was reduced by $96 \%, 98 \%$, and $99 \%$ respectively $(P<0.001$ in all cases). The de-

\section{A}

\section{ENDOMETRIOTIC CELL PROLIFERATION}

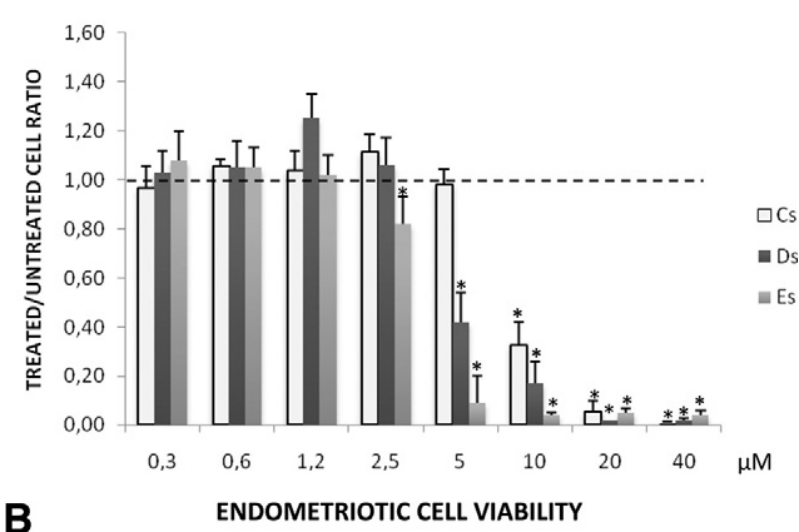

B

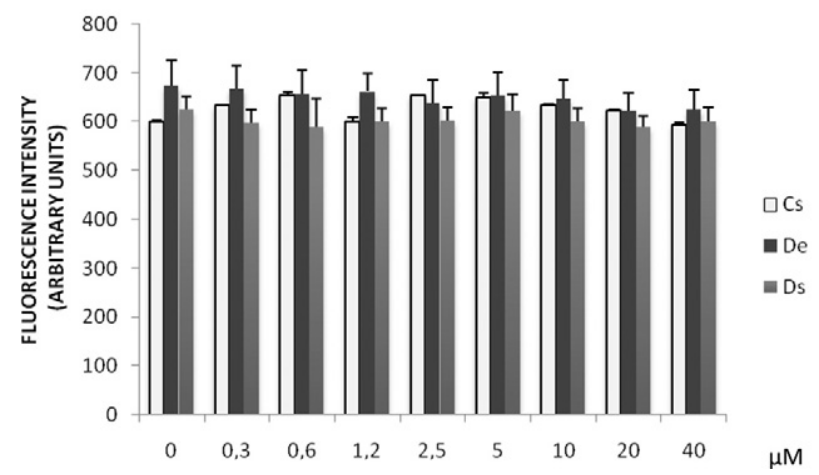

Figure 2. Effect of WIN 55212-2 on cell proliferation and cell viability. A: Proliferative rate of each stromal endometriotic cell line (11 eutopic endometrial stromal cell lines, Es, and 14 deep infiltrating endometriotic stromal cell lines, Ds) and of three control endometrial stromal cell lines (Cs) treated in vitro with increasing concentrations $(0.3-40 \mu \mathrm{mol} / \mathrm{L})$ of WIN 55212-2. Black dotted line shows the basal level of proliferation of untreated endometriotic cells. Cell proliferation was determined by thymidine incorporation. Results are expressed as ratios of treated versus untreated cells: ${ }^{*} P<0.05$. B: Cell viability of each stromal endometriotic cell line (11 eutopic endometrial stromal cell lines, Es, and 14 deep infiltrating endometriotic stromal cell lines, Ds) and of three control endometrial stromal cell lines (Cs) untreated or treated in vitro with increasing concentrations $(0.3$ to $40 \mu \mathrm{mol} / \mathrm{L})$ of WIN 55212-2. Analysis by Hoechst 33342 staining. Fluorescence intensity was recorded with a fluorescence excitation/emission maxima of $350 / 461 \mathrm{~nm}$. crease was dose-dependent and not significant at concentrations below $5 \mu \mathrm{mol} / \mathrm{L}$ (Cs), $2.5 \mu \mathrm{mol} / \mathrm{L}$ (Ds), and $1.25 \mu \mathrm{mol} / \mathrm{L}$ (Es) (Figure 2A).

At $5 \mu \mathrm{mol} / \mathrm{L}$, the proliferative rate of Ds cells and $\mathrm{Es}$ cells were significantly decreased by $57 \%(P<0.01)$ and $72 \%(P<0.001)$ respectively compared to Cs (Figure 2A). At $1.25 \mu \mathrm{mol} / \mathrm{L}$, the proliferative rate of Ds cells was significantly increased by $98 \%(P<0.001)$ (Figure $2 A)$.

\section{A}

EFFECT OF WIN 55212-2 $\mathrm{ON} \mathrm{O}_{2}{ }^{--}$

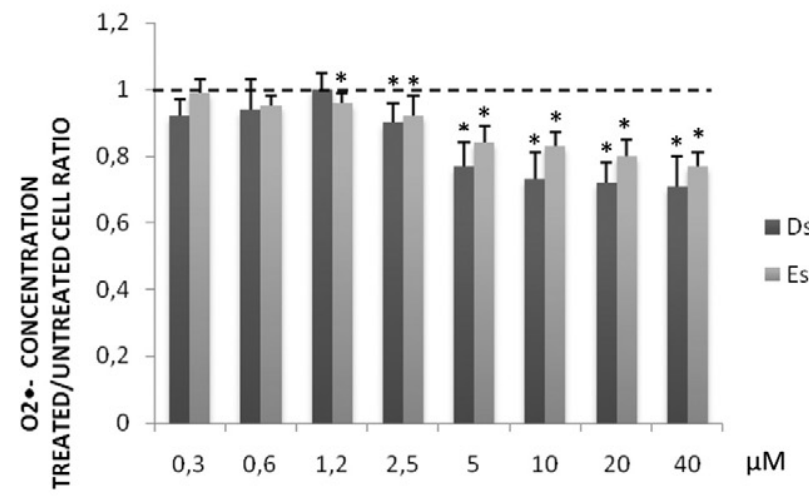

B

EFFECT OF WIN 55212-2 ON H2 $\mathrm{O}_{2}$

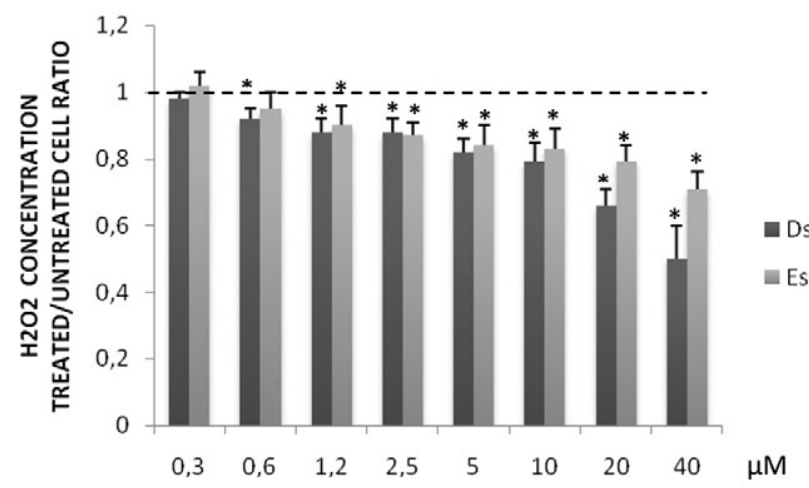

C

EFFECT OF WIN 55212-2 ON NO

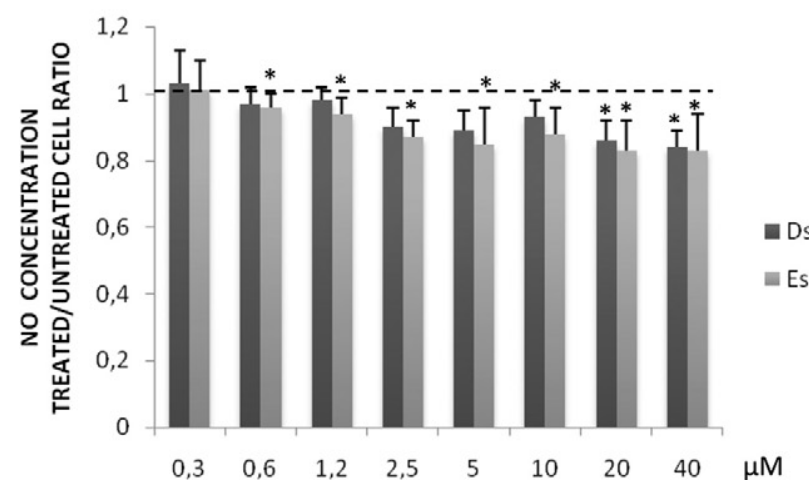

Figure 3. Effect of WIN 55212-2 on ROS production. Productions of $\mathrm{O}_{2}^{--}$(A) $\mathrm{H}_{2} \mathrm{O}_{2}(\mathbf{B})$, and $\mathrm{NO}(\mathbf{C})$ in each stromal endometriotic cell line (11 eutopic endometrial stromal cell lines, Es, and 14 deep infiltrating endometriotic stromal cell lines, Ds) treated in vitro with increasing concentrations ( 0.3 to $40 \mu \mathrm{mol} / \mathrm{L}$ ) of WIN 55212-2 compared to untreated cells. Black dotted line shows the basal level of production in untreated cells. Production of ROS was assessed by spectrofluorometry using specific fluorochromes. Results are expressed as ratios of treated versus untreated cells: ${ }^{*} P<0.05$. 
Effect of WIN 55212-2 on the Viability of

\section{Endometriotic Stromal Cells}

WIN 55212-2 was not cytotoxic to Es and Ds cells at the concentration tested as shown by Hoechst 33342 staining (Figure 2B).

\section{Effect of WIN 55212-2 on the Endogenous Production of Reactive Oxygen Species by Endometriotic Stromal Cells}

\section{Production of Superoxide Anions $\left(\mathrm{O}_{2}^{--}\right)$}

Using $40 \mu \mathrm{mol} / \mathrm{L}$ WIN 55212-2, the production of $\mathrm{O}_{2}^{--}$in Es and Ds cells was significantly reduced by $23 \%$ and $39 \%$, respectively (Figure 3A, $P<0.001$ in both cases). The production of $\mathrm{O}_{2}^{--}$was dose-dependently decreased and was not significant below $1.25 \mu \mathrm{mol} / \mathrm{L}$.

\section{Production of $\mathrm{H}_{2} \mathrm{O}_{2}$}

Using $40 \mu \mathrm{mol} / \mathrm{L}$ WIN 55212-2, the production of $\mathrm{H}_{2} \mathrm{O}_{2}$ in Es and Ds cells was significantly reduced by $29 \%$ and

\section{A}

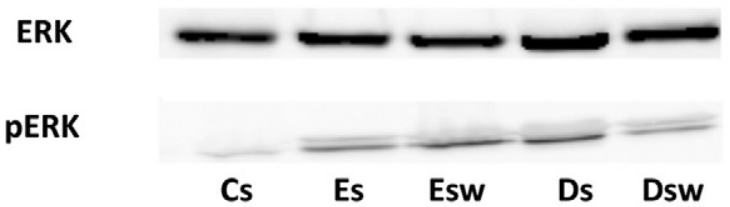

B EFFECT OF WIN 55212-2 ON ERK PATHWAY

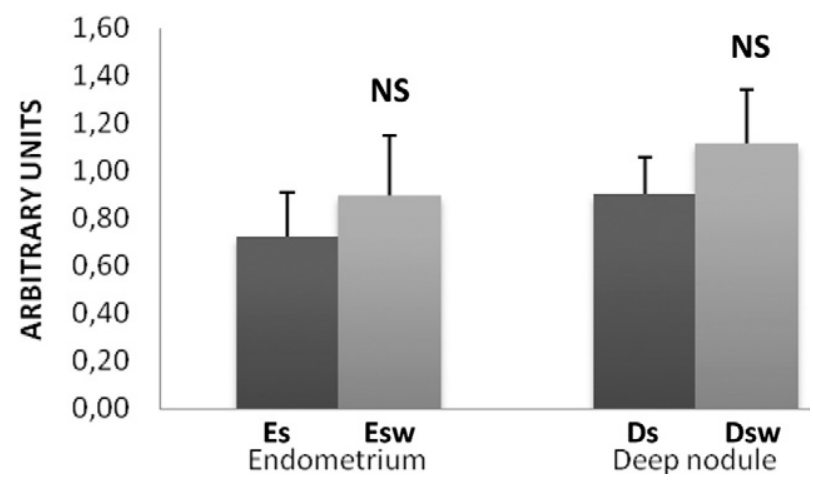

Figure 4. Effect of WIN 55212-2 on ERK pathway. A: Representative Western blot of ERK and pERK. Western blotting of ERK and pERK were performed on lysates of each untreated stromal cell line (10 control endometrial stromal cell lines, Cs, 11 eutopic endometrial stromal cell lines, Es, and 14 deep infiltrating endometriotic stromal cell lines, Ds) and on lysates of each stromal cell line treated in vitro by $20 \mu \mathrm{mol} / \mathrm{L}$ of WIN 55212-2 (11 eutopic endometrial stromal cell lines, Esw, and 14 deep infiltrating endometriotic stromal cell lines, Dsw) using specific anti-ERK and anti-pERK antibodies. B: Quantitative analysis of ERK and pERK. Quantitative analysis of ERK and pERK was performed in each untreated stromal endometriotic cell line (11 eutopic endometrial stromal cell lines, Es, and 14 deep infiltrating endometriotic stromal cell lines, Ds) and in each stromal endometriotic cell line treated in vitro by $20 \mu \mathrm{mol} / \mathrm{L}$ WIN 55212-2 (11 eutopic endometrial stromal cell lines, Esw, and 14 deep infiltrating endometriotic stromal cell lines, Dsw). The mean optical density ratio pERK/ERK was calculated in each endometriotic cell type. NS: no significant.
$50 \%$, respectively (Figure 3B, $P<0.001$ in both cases). The production of $\mathrm{H}_{2} \mathrm{O}_{2}$ was dose-dependently decreased and was not significant below $0.6 \mu \mathrm{mol} / \mathrm{L}$.

\section{Production of NO}

Using $40 \mu \mathrm{mol} / \mathrm{L}$ WIN 55212-2, the production of $\mathrm{NO}$ in Es and Ds cells was significantly reduced by $17 \%$ and $16 \%$, respectively (Figure $3 \mathrm{C}, P<0.05$ in both cases). The production of NO was dose-dependently decreased and was not significant below $10 \mu \mathrm{mol} / \mathrm{L}$ (Ds) and $0.3 \mu \mathrm{mol} / \mathrm{L}$ (Es).

\section{A}

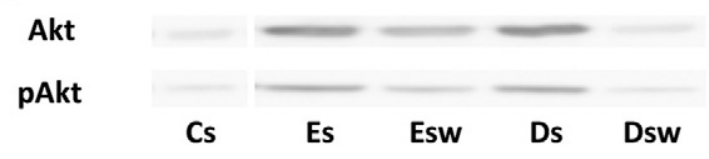

B EFFECT OF WIN 55212-2 ON AKT PATHWAY

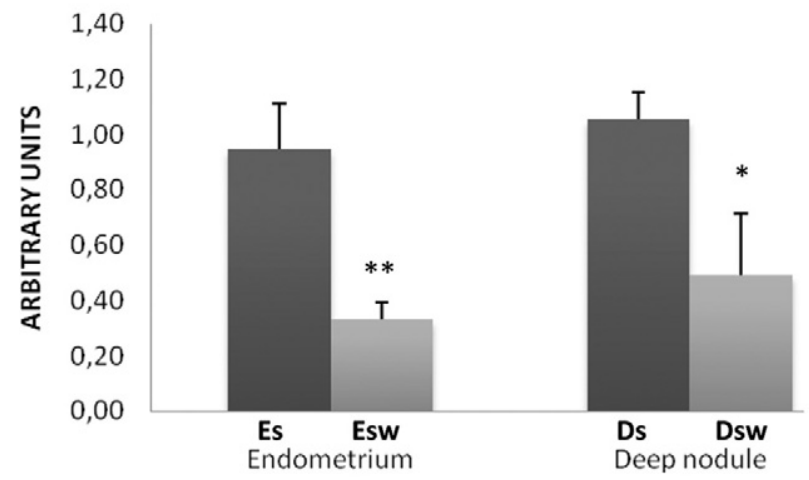

C

EFFECT OF WIN 55212-2 ON PAKT PATHWAY

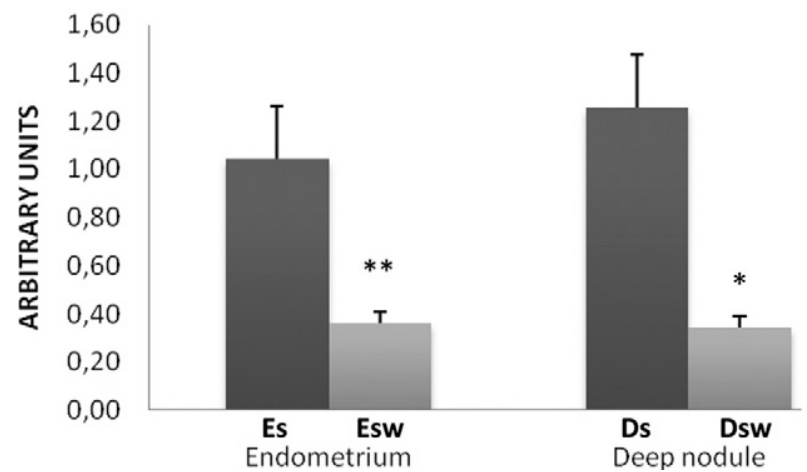

Figure 5. Effect of WIN 55212-2 on Akt pathway. A: Representative Western blot of Akt and pAkt. Western blotting of Akt and pAkt were performed on lysates of each untreated stromal cell line (10 control endometrial stromal cell lines, Cs, 11 eutopic endometrial stromal cell lines, Es, and 14 deep infiltrating endometriotic stromal cell lines, Ds) and on lysates of each stromal cell line treated in vitro by $20 \mu \mathrm{mol} / \mathrm{L}$ of WIN 55212-2 (11 eutopic endometrial stromal cell lines, Esw, and 14 deep infiltrating endometriotic stromal cel lines, Dsw) using specific anti-Akt and anti-pAkt, antibodies. B: Quantitative analysis of Akt and (C) quantitative analysis of pAkt. Quantitative analysis of Akt and pAkt was performed in each untreated stromal endometriotic cell line (11 eutopic endometrial stromal cell lines, Es, and 14 deep infiltrating endometriotic stromal cell lines, Ds) and in each stromal endometriotic cell line treated in vitro by $20 \mu \mathrm{mol} / \mathrm{L}$ WIN 55212-2 (11 eutopic endometrial stromal cell lines, Esw, and 14 deep infiltrating endometriotic stromal cell lines, Dsw). The mean optical density of Akt and pAkt were calculated in each endometriotic cell type: ${ }^{*} P<0.05$, ${ }^{* * *} P<0.01$. 


\section{Effect of WIN 55212-2 on the ERK Pathway}

The ERK protein was equally present in the stromal cell lines derived from control endometrium (Cs), eutopic endometrium from untreated and treated patients (Es, Esw) and deep infiltrating endometriotic nodules from untreated and treated patients (Ds, Dsw). The phosphorylated activated form of ERK, pERK, was undetectable in Cs cells but equally present in Es, Esw, Ds, and Dsw cells (Figure 4A).

The differences were significant neither between Esw cells and Es cells, nor between Dsw and Ds cells (Figure 4B).

\section{Effect of WIN 55212-2 on the Akt Pathway}

The Akt protein and its phosphorylated activated form, pAkt, were undetectable in Cs cells. Akt and pAkt were present in cell lines derived from patients but at higher levels in Es cells and in Ds cells than in Esw cells and in Dsw cells (Figure 5A).

Akt level was reduced by $65 \%$ in Esw cells versus Es cells $(P<0.01)$ and by $50 \%$ in Dsw cells versus Ds cells $(P<0.05)$ (Figure 5B).

pAkt level was reduced by $65 \%$ in Esw cells versus Es cells $(P<0.01)$ and by $73 \%$ in Dsw cells versus Ds cells $(P<0.01)$ (Figure 5C).

A

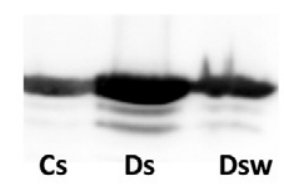

B

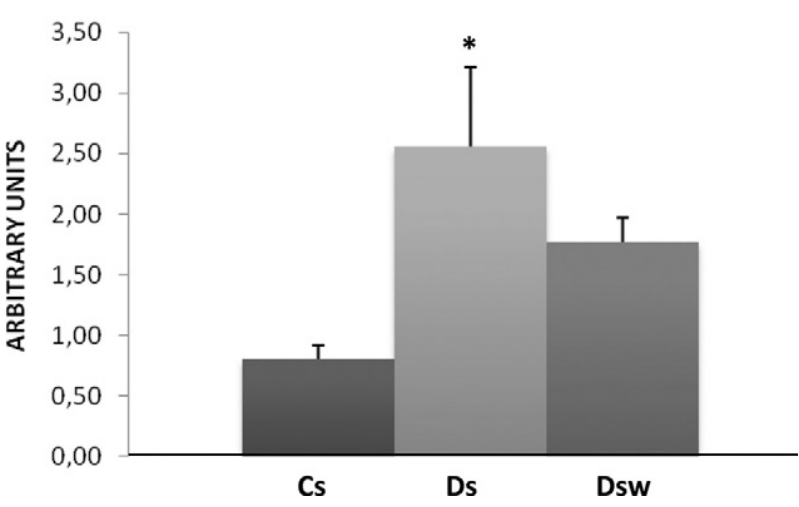

Figure 6. Effect of WIN 55212-2 on expression of $\alpha$ SMA. A: Representative Western blot of $\alpha$ SMA. Western blotting of $\alpha$ SMA was performed on lysates of each untreated stromal cell line (10 control endometrial stromal cells, Cs, and 14 deep infiltrating endometriotic stromal cells, Ds) and in each 14 deep infiltrating endometriotic stromal treated in vitro by $20 \mu \mathrm{mol} / \mathrm{L}$ WIN 55212-2 (Dsw) using specific antibody anti- $\alpha$ SMA. B: Quantitative analysis of $\alpha$ SMA Quantitative analysis of $\alpha$ SMA was performed in each untreated cell line (10 control endometrial stromal cells, Cs, and 14 untreated deep infiltrating endometriotic stromal cells, Ds) and in each 14 deep infiltrating endometriotic stromal cell line treated in vitro by $20 \mu \mathrm{mol} / \mathrm{L}$ WIN 55212-2 (Dsw). The mean optical density of $\alpha$ SMA was calculated in each endometriotic cell type: ${ }^{*} P<0.05$.

\section{Expression of $\alpha S M A$ by Deep Infiltrating Endometriotic Stromal Cells}

The $\alpha$ SMA protein was present in CS cells, Ds cells and Dsw cells, but in higher amounts in Ds cells (Figure 6A). $\alpha \mathrm{SMA}$ level was threefold higher in Ds cells than in Cs cells $(P<0.05)$. Its decrease $(30 \%)$ in Dsw cells compared to Ds cells did not reach significance Figure 6B).

\section{Mouse Model}

Fourteen nude mice were grafted with two fragments of nodules from one patient with DIE. Two mice died immediately after surgery and one mouse died on day 1 in the aftermath of an evisceration. Two fragments of nodules were removed, one on day 7 for lack of implantation and one on day 21 because of an abscess. The control group included six mice with 11 implants and the treated group included five mice with 9 implants.

In control mice, there was no difference between the volume of DIE implants on day $0\left(59.3 \mathrm{~mm}^{3}\right)$ and the volume of DIE implants on day $21\left(64.5 \mathrm{~mm}^{3}\right)$. In treated mice, the volume of DIE implants on day 21 was reduced by $41 \%$ compared to the volume of DIE implants on day 0 (36.7 $\mathrm{mm}^{3}$ versus $62.1 \mathrm{~mm}^{3}$, respectively, $\left.P<0.01\right)$. On day 21, the volume of DIE implants in treated mice was reduced by $43 \%$ compared to the volume of DIE

\section{A}

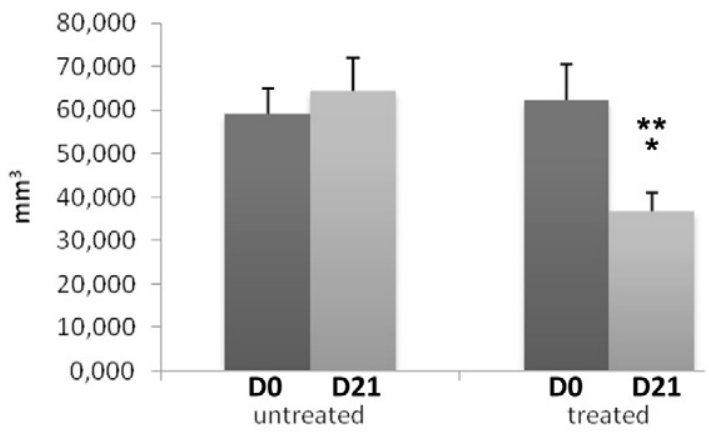

B
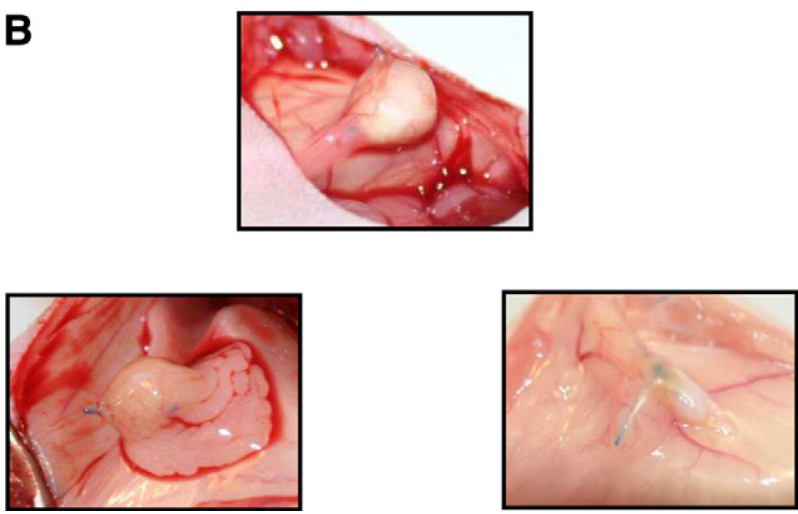

Figure 7. Effect on WIN 55212-2 on deep infiltrating endometriotic tissue on mouse model. A: Volumes of implants were calculated on days 0 and 21 of untreated and treated mice. Volumes on day 21 versus volumes on day 0 : ${ }^{*} P<0.01$; volumes on day 21 in treated mice versus untreated mice: ${ }^{* *} P<$ 0.01. B: Macroscopic views of deep infiltrating implant in untreated mice (top) and in treated mice on days 0 and 21 (bottom). 
implants in control mice $\left(36.7 \mathrm{~mm}^{3}\right.$ versus $64.5 \mathrm{~mm}^{3}$ respectively, $P<0.01$ ) (Figure $7 \mathrm{~A}$ and $\mathrm{B}$ ).

\section{Discussion}

This report describes the effects of WIN 55212-2, a cannabinoid agonist, on deep infiltrating endometriotic cell proliferation, and also its on fibrosis which is another characteristic of DIE.

WIN 55212-2 was chosen because it is a nonselective agonist and because both types of cannabinoid receptors, CB1 and CB2, are expressed by stromal and epithelial cells in the eutopic endometrium, in the deep infiltrating endometriotic nodules and in the healthy endometrium as well. The antiproliferative effect of WIN 55212-2 is more powerful on eutopic endometrial stromal cells and deep infiltrating endometriotic stromal cells than on control endometrial stromal cells. This can be explained by the hyperproliferative phenotype of endometriotic cells compared to normal endometrial cells. An antiproliferative effect of cannabinoid agonists has already been reported in cancer, in particular breast cancer, ${ }^{15}$ prostate cancer, ${ }^{15,16}$ colorectal cancer, ${ }^{37}$ and melanoma. ${ }^{38}$ The antiproliferative effect of this molecule on endometriotic cells is not so surprising since cancer cells that have several metabolic characteristics in common with endometriotic cells. ${ }^{21}$ Reciprocally, we have already shown that 5-FU, an antimetabolite commonly used in the treatment of cancer was effective in DIE. ${ }^{39}$

To understand the mechanism of the antiproliferative properties of WIN 55212-2, we have studied the effects of the molecule on the endogenous oxidative stress, which is increased in endometriotic cells. ${ }^{10}$ At high concentrations of WIN 55212-2, the inhibition of $\mathrm{O}_{2}^{--}$and $\mathrm{H}_{2} \mathrm{O}_{2}$ productions was higher in the deep infiltrating endometriotic stromal cells than in the eutopic endometrial stromal cells. The regulation of ROS production by cannabinoid agonists has also been shown in macrophages ${ }^{40}$ and in cardiomyocytes. ${ }^{41}$

ROS have been shown to increase the proliferation of endometriotic cells through the activation of ERK $1 / 2$. Therefore, the decreased production of ROS by WIN could have led to a decrease in ERK activation. Despite the decrease in ROS production and the decreased proliferation of endometriotic cells by WIN, ERK $1 / 2$ activation remained stable in WIN-treated endometriotic cells. On the other hand, a direct activation of ERK by WIN has been shown. ${ }^{17,38}$ This agonistic effect could have been neutralized in endometriotic cells by the antioxidant effect of win on those cells. This result rules out the involvement of the ERK pathway as the one involved in the control of endometriotic cell proliferation by WIN.

On the other hand, the Akt pathway which is involved in the antiproliferative effect of cannabinoids, ${ }^{42,43}$ has never been explored in endometriosis. In our hands, WIN 55212-2 inactivates the Akt pathway. ROS having few interactions with the Akt pathway, this data confirms the absence of connection between the antioxidant effects of WIN and its antiproliferative effects that appear to be mediated by the Akt pathway.
These data could also explain the absence of cytotoxic effect of WIN 55212-2 on endometriotic cells although cannabinoid agonists have a cytotoxic effect on various cells including glial cells, ${ }^{42}$ human T-cell lymphoma, ${ }^{43}$ breast cancer ${ }^{44}$ or prostate cancer. ${ }^{45}$ Actually, the apoptosis induced by cannabinoid agonists in glial cells of rats is initiated by the combined inhibitions of ERK and Akt pathways. ${ }^{42}$ In our model, the absence of cytotoxicity of WIN 55212-2 on endometriotic cells can be explained by the noninhibition of the ERK pathway.

The second benefit potentially expected from the use of cannabinoid agonists in patients with DIE is the inhibition of the fibrotic process. In our hand, WIN 55212-2 inhibits $\alpha$ SMA expression, a marker of myofibroblastic transformation. The antifibrotic property of those substances has been already demonstrated in the skin, ${ }^{22}$ in the heart, ${ }^{23}$ in the pancreas, ${ }^{26}$ and in the liver, ${ }^{25,28}$ where they exert a curative effect on fibrosis. ${ }^{27}$ In vitro, the synthesis of type I collagen by fibroblasts from skin biopsies of patients with diffuse systemic sclerosis ${ }^{24}$ is selectively inhibited by cannabinoid agonists. Limiting the fibrotic process, as shown in our experiments, would allow a less extensive surgery.

In the last part of this report we confirm the antiproliferative effect of WIN 55212-2 in an in vivo model of endometriosis in nude mice. In most studies, the lifetime of implants in nude mice does not exceed 4 weeks. Then a dedifferentiation appears and a B cell infiltrate occurs from the third week on. ${ }^{36}$ We have circumvented this difficulty by sacrificing the mice 15 days after implantation. Mortality was less than $25 \%$ and the implantation rate was above $90 \%$ which is similar to the data published. ${ }^{36}$ After 2 weeks, the treatment by WIN 55212-2 proved effective with a significant decrease in the volume of the implants.

In conclusion, WIN 55212-2 has in vitro antiproliferative and antifibrotic effects in deep infiltrating endometriotic cells. The antiproliferative effect is linked to the inactivation of the Akt pathway. The effectiveness of WIN 55212-2 in vitro, confirmed in vivo in a mouse model of DIE, suggests that the cannabinoid agonists represent a promising therapeutic approach in the treatment of DIE.

\section{Acknowledgment}

The authors are grateful to Ms. Agnes Colle for editing the manuscript.

\section{References}

1. Giudice LC, Kao LC: Endometriosis. Lancet 2004, 364:1789-1799

2. Berkley KJ, Rapkin AJ, Papka RE: The pains of endometriosis. Science 2005, 308:1587-1589

3. Chapron C, Bourret A, Chopin N, Dousset B, Leconte M, AmsellemOuazana D, de Ziegler D, Borghese B: Surgery for bladder endometriosis: long-term results and concomitant management of associated posterior deep lesions. Hum Reprod 25:884-889

4. Chapron C, Fauconnier A, Dubuisson JB, Barakat H, Vieira M, Breart G: Deep infiltrating endometriosis: relation between severity of dysmenorrhoea and extent of disease. Hum Reprod 2003, 18:760-766

5. Koninckx PR, Meuleman C, Demeyere S, Lesaffre E, Cornillie FJ: 
Suggestive evidence that pelvic endometriosis is a progressive disease, whereas deeply infiltrating endometriosis is associated with pelvic pain. Fertil Steril 1991, 55:759-765

6. Laursen BS, Bajaj P, Olesen AS, Delmar C, Arendt-Nielsen L: Health related quality of life and quantitative pain measurement in females with chronic non-malignant pain. Eur J Pain 2005, 9:267-275

7. De Ziegler D, Borghese B, Chapron C: Endometriosis and infertility: pathophysiology and management. Lancet 2010, 376:730-738

8. Bonte $\mathrm{H}$, Chapron $\mathrm{C}$, Vieira $\mathrm{M}$, Fauconnier A, Barakat $\mathrm{H}$, Fritel $\mathrm{X}$, Vacher-Lavenu MC, Dubuisson JB: Histologic appearance of endometriosis infiltrating uterosacral ligaments in women with painful symptoms. J Am Assoc Gynecol Laparosc 2002, 9:519-524

9. Dousset B, Leconte M, Borghese B, Millischer AE, Roseau G, Arkwright S, Chapron C: Complete surgery for low rectal endometriosis: long-term results of a 100-case prospective study. Ann Surg 251:887-895

10. Ngo C, Chereau C, Nicco C, Weill B, Chapron C, Batteux F: Reactive oxygen species controls endometriosis progression. Am J Pathol 2009, 175:225-234

11. Klein TW: Cannabinoid-based drugs as anti-inflammatory therapeutics. Nat Rev Immunol 2005, 5:400-411

12. Bifulco M, Di Marzo V: Targeting the endocannabinoid system in cancer therapy: a call for further research. Nat Med 2002, 8:547-550

13. Guzman M, Sanchez C, Galve-Roperh I: Cannabinoids and cell fate. Pharmacol Ther 2002, 95:175-184

14. Pisanti S, Borselli C, Oliviero O, Laezza C, Gazzerro P, Bifulco M: Antiangiogenic activity of the endocannabinoid anandamide: correlation to its tumor-suppressor efficacy. J Cell Physiol 2007, 211: 495-503

15. De Petrocellis L, Melck D, Palmisano A, Bisogno T, Laezza C, Bifulco M, Di Marzo V: The endogenous cannabinoid anandamide inhibits human breast cancer cell proliferation. Proc Natl Acad Sci USA 1998 95:8375-8380

16. Melck D, De Petrocellis L, Orlando P, Bisogno T, Laezza C, Bifulco M, Di Marzo V: Suppression of nerve growth factor Trk receptors and prolactin receptors by endocannabinoids leads to inhibition of human breast and prostate cancer cell proliferation. Endocrinology 2000 $141: 118-126$

17. Gomez del Pulgar T, Velasco G, Sanchez C, Haro A, Guzman M: De novo-synthesized ceramide is involved in cannabinoid-induced apoptosis. Biochem J 2002, 363:183-188

18. Bouaboula M, Poinot-Chazel C, Bourrie B, Canat X, Calandra B, Rinaldi-Carmona M, Le Fur G, Casellas P: Activation of mitogenactivated protein kinases by stimulation of the central cannabinoid receptor CB1. Biochem J 1995, 312 (Pt 2):637-641

19. Rueda D, Galve-Roperh I, Haro A, Guzman M: The CB(1) cannabinoid receptor is coupled to the activation of c-Jun N-terminal kinase. Mol Pharmacol 2000, 58:814-820

20. Fogli S, Breschi M: The molecular bases of cannabinoid action in cancer. Cancer Ther 2008, 6:103-116

21. Varma R, Rollason T, Gupta JK, Maher ER: Endometriosis and the neoplastic process. Reproduction 2004, 127:293-304

22. Akhmetshina A, Dees C, Busch N, Beer J, Sarter K, Zwerina J, Zimmer A, Distler O, Schett G, Distler JH: The cannabinoid receptor CB2 exerts antifibrotic effects in experimental dermal fibrosis. Arthritis Rheum 2009, 60:1129-1136

23. Defer N, Wan J, Souktani R, Escoubet B, Perier M, Caramelle P, Manin S, Deveaux V, Bourin MC, Zimmer A, Lotersztajn S, Pecker F, Pavoine C: The cannabinoid receptor type 2 promotes cardiac myocyte and fibroblast survival and protects against ischemia/reperfusion-induced cardiomyopathy. FASEB J 2009, 23:2120-2130

24. Garcia-Gonzalez E, Selvi E, Balistreri E, Lorenzini S, Maggio R, Natale MR, Capecchi PL, Lazzerini PE, Bardelli M, Laghi-Pasini F, Galeazzi $\mathrm{M}$ : Cannabinoids inhibit fibrogenesis in diffuse systemic sclerosis fibroblasts. Rheumatology (Oxford) 2009, 48:1050-1056

25. Julien B, Grenard P, Teixeira-Clerc F, Van Nhieu JT, Li L, Karsak M, Zimmer A, Mallat A, Lotersztajn S: Antifibrogenic role of the cannabinoid receptor CB2 in the liver. Gastroenterology 2005, 128:742-755

26. Michalski CW, Maier M, Erkan M, Sauliunaite D, Bergmann F, Pacher $\mathrm{P}$, Batkai S, Giese NA, Giese T, Friess H, Kleeff J: Cannabinoids reduce markers of inflammation and fibrosis in pancreatic stellate cells. PLoS One 2008, 3:e1701
27. Munoz-Luque J, Ros J, Fernandez-Varo G, Tugues S, Morales-Ruiz M, Alvarez CE, Friedman SL, Arroyo V, Jimenez W: Regression of fibrosis after chronic stimulation of cannabinoid CB2 receptor in cirrhotic rats. J Pharmacol Exp Ther 2008, 324:475-483

28. Teixeira-Clerc F, Julien B, Grenard P, Tran Van Nhieu J, Deveaux V Li L, Serriere-Lanneau V, Ledent C, Mallat A, Lotersztajn S: CB1 cannabinoid receptor antagonism: a new strategy for the treatment of liver fibrosis. Nat Med 2006, 12:671-676

29. Guindon J, Hohmann AG: Cannabinoid CB2 receptors: a therapeutic target for the treatment of inflammatory and neuropathic pain. $\mathrm{Br} \mathrm{J}$ Pharmacol 2008, 153:319-334

30. Pacher P, Batkai S, Kunos G: The endocannabinoid system as an emerging target of pharmacotherapy. Pharmacol Rev 2006, 58:389462

31. Tsou K, Lowitz KA, Hohmann AG, Martin WJ, Hathaway CB, Bereiter DA, Walker JM: Suppression of noxious stimulus-evoked expression of Fos protein-like immunoreactivity in rat spinal cord by a selective cannabinoid agonist. Neuroscience 1996, 70:791-798

32. Hornung D, Ryan IP, Chao VA, Vigne JL, Schriock ED, Taylor RN Immunolocalization and regulation of the chemokine RANTES in human endometrial and endometriosis tissues and cells. J Clin Endocrinol Metab 1997, 82:1621-1628

33. Laurent A, Nicco C, Chereau C, Goulvestre C, Alexandre J, Alves A, Levy E, Goldwasser F, Panis Y, Soubrane O, Weill B, Batteux F: Controlling tumor growth by modulating endogenous production of reactive oxygen species. Cancer Res 2005, 65:948-956

34. Song JS, Kang CM, Yoo MB, Kim SJ, Yoon HK, Kim YK, Kim KH, Moon HS, Park SH: Nitric oxide induces MUC5AC mucin in respiratory epithelial cells through PKC and ERK dependent pathways. Respir Res 2007, 8:28

35. Bruner-Tran KL, Webster-Clair D, Osteen KG: Experimental endometriosis: the nude mouse as a xenographic host. Ann NY Acad Sci 2002, 955: 328-339; discussion 340-322, 396-406

36. Grummer R, Schwarzer F, Bainczyk K, Hess-Stumpp H, Regidor PA, Schindler AE, Winterhager E: Peritoneal endometriosis: validation of an in-vivo model. Hum Reprod 2001, 16:1736-1743

37. Ligresti A, Bisogno T, Matias I, De Petrocellis L, Cascio MG, Cosenza V, D’Argenio G, Scaglione G, Bifulco M, Sorrentini I, Di Marzo V: Possible endocannabinoid control of colorectal cancer growth. Gastroenterology 2003, 125:677-687

38. Blazquez C, Carracedo A, Barrado L, Real PJ, Fernandez-Luna JL, Velasco G, Malumbres M, Guzman M: Cannabinoid receptors as novel targets for the treatment of melanoma. FASEB J 2006, 20:2633-2635

39. Ngo C, Nicco C, Leconte M, Chereau C, Weill B, Batteux F, Chapron C: Antiproliferative effects of anastrozole, methotrexate, and 5-fluorouracil on endometriosis in vitro and in vivo. Fertil Steril 2009, 94:1632-1638

40. Han KH, Lim S, Ryu J, Lee CW, Kim Y, Kang JH, Kang SS, Ahn YK, Park CS, Kim JJ: CB1 and CB2 cannabinoid receptors differentially regulate the production of reactive oxygen species by macrophages. Cardiovasc Res 2009, 84:378-386

41. Mukhopadhyay P, Rajesh M, Batkai S, Patel V, Kashiwaya Y, Liaudet L, Evgenov OV, Mackie K, Hasko G, Pacher P: CB1 cannabinoid receptors promote oxidative stress and cell death in murine models of doxorubicin-induced cardiomyopathy and in human cardiomyocytes. Cardiovasc Res 85:773-784

42. Ellert-Miklaszewska A, Kaminska B, Konarska L: Cannabinoids downregulate $\mathrm{P} \mid 3 \mathrm{~K} / \mathrm{Akt}$ and Erk signalling pathways and activate proapoptotic function of Bad protein. Cell Signal 2005, 17:25-37

43. Jia W, Hegde VL, Singh NP, Sisco D, Grant S, Nagarkatti M, Nagarkatti PS: Delta9-tetrahydrocannabinol-induced apoptosis in Jurkat leukemia T cells is regulated by translocation of Bad to mitochondria. Mol Cancer Res 2006, 4:549-562

44. McKallip RJ, Nagarkatti M, Nagarkatti PS: Delta-9-tetrahydrocannabinol enhances breast cancer growth and metastasis by suppression of the antitumor immune response. J Immunol 2005, 174:3281-3289

45. Sarfaraz S, Afaq F, Adhami VM, Malik A, Mukhtar H: Cannabinoid receptor agonist-induced apoptosis of human prostate cancer cells LNCaP proceeds through sustained activation of ERK1/2 leading to G1 cell cycle arrest. J Biol Chem 2006, 281:39480-39491 